\title{
Monitoring Bank Performance in the Presence of Risk
}

\author{
Mircea Epure* \\ Department of Economics and Business, Universitat Pompeu Fabra and Barcelona GSE \\ mircea.epure@upf.edu \\ Esteban Lafuente \\ Department of Management, Universitat Politècnica de Catalunya (Barcelona Tech) \\ esteban.lafuente@upc.edu
}

March 2012. This version: May 2012

\begin{abstract}
This paper devises management and accounting tools for monitoring bank performance. We first propose a multidimensional efficiency measure that integrates credit risk and is adapted to the real banking technology. Second, traditional accounting ratios complement the analysis. Third, the impact of different risk measures over efficiency and accounting ratios is shown. Fourth, we examine the effect of CEO turnover on future performance. An empirical application considers a unique dataset of Costa Rican banks during 1998-2007. Results reveal that performance improvements follow regulatory changes and that risk explains differences in performance. Non-performing loans negatively affect efficiency and return on assets, whereas the capital adequacy ratio positively affects the net interest margin. This supports that incurring monitoring costs and having higher levels of capitalisation may enhance performance. Finally, results confirm that appointing CEOs from outside the bank significantly improves performance, thus suggesting the potential benefits of new organisational practices.
\end{abstract}

Keywords: efficiency; accounting; performance; risk; CEO turnover

\footnotetext{
${ }^{*}$ Corresponding author
} 


\section{Introduction}

Recent banking studies analysed the impact of risk on performance and, on occasions, attempted to introduce risk measures in performance assessments (see, e.g., Hughes and Mester (1998), Altunbas et al. (2000), Park and Weber (2006), Banker et al. (2010), Hsiao et al. (2010) or Barros et al. (2012)). There remains, however, a need to unify these approaches by using risk factors as an integrating part of performance analyses. This implies that risk has endogenous components (Van Hoose 2010). Therefore, it is necessary to develop monitoring tools to thoroughly examine the relations between risk and performance. Moreover, new assessments should be accurate enough to simultaneously accommodate the multiple bank outputs, reflect the true technology, and speak the language of management and accounting communities. Thus, this paper takes a monitoring approach to devise a framework for bank performance analysis with the above characteristics. First, a multidimensional efficiency measure is defined to include desirable and undesirable outputs, the latter of which represent credit risk. Second, accounting performance ratios complement the efficiency interpretations to attain more traditional management viewpoints. Third, the impact of risk variables on all performance measures is shown. Finally, the effect of executive turnover on future performance is evaluated.

Bank efficiency has been analysed from multiple angles (see, e.g., the reviews of Berger and Humphrey (1997), Goddard et al. (2001) or Fethi and Pasiouras (2010)). Among these, a largely preferred approach relies on non-parametric efficiency frontier techniques. These methods, best known as Data Envelopment Analysis (DEA) are more suitable when multiple inputs are employed to obtain multiple outputs (see, e.g., Ray (2004)). Even if parametric models allow for stochastic errors, they have strong assumptions on functional distributions (which are not needed in non-parametric contexts) and do not allow for multiple objectives to be pursued or desirable and undesirable outputs to be jointly produced. The flexible nature of DEA is especially appealing for applications based on diverse management and accounting frameworks (Grifell-Tatjé and Lovell 1999; Banker et al. 2005). Hence, the literature on non-parametric efficiency analysis has experienced important developments (Cook and Seiford 2009; Cooper et al. 2011).

Although the efficiency of banks has been vastly scrutinised, few studies introduced risk variables in efficiency measures. Initially, parametric analyses did so under cost function approaches (McAllister and McManus 1993; Berger and DeYoung 1997; Hughes and Mester 1998; Altunbas et al. 2000). For instance, Hughes and Mester (1998) used the level of financial capital as a risk signal that bank managers use for controlling output quality. Altunbas et al. (2000) express loan portfolio quality through the ratio of non-performing loans (NPL) to total loans, which may be considered an endogenous measure of risk. According to Berger and DeYoung (1997) and Van Hoose (2010) this variable captures the quality of monitoring over loan portfolios. There also exists a stream of literature that introduces risk in non-parametric bank efficiency analysis (Park and Weber 2006; Fukuyama and Weber 2010; Barros et al. 2012). In this case, risk takes the form of undesirable outputs, and for 
financial institutions it is typically proxied through NPL. This variable illustrates credit risk, which is crucial for the long-run bank activity (Basel Committee of Banking Supervision 2011).

Yet, this latter stream of literature leaves two unaddressed issues. First, in typical production settings with desirable and undesirable outputs, their joint production is consistent in the sense that producing desirable outputs is not possible without producing undesirable outputs. This may not apply to bank production, in which only certain outputs are linked to undesirable outputs such as NPL. Second, existing non-parametric banking studies that introduce credit risk in efficiency assessments often assume constant returns to scale, whereas the technology is more likely to exhibit variable returns to scale (Chambers and Pope 1996).

To address these issues, a first contribution of this paper is to accurately define tools for monitoring bank performance that integrate endogenous risk (i.e. credit risk) in the efficiency analyses. As a baseline we use the specification of Kuosmanen (2005) that properly models desirable and undesirable outputs when assuming variable returns to scale. This is further adapted to define the real banking technology. Particularly, undesirable outputs, NPL, are strictly linked only to that dimension of the output set that refers to credit (i.e. loan portfolio). The rest of outputs, such as investment portfolio or service fees, do not have a link with NPL.

Second, to achieve a comprehensive image of bank performance, this multidimensional efficiency assessment is complemented and compared with conventional accounting ratios defined as return on assets (ROA) and net interest margin (NIM). Furthermore, second stage analyses introduce, along with internal credit risk, a risk variable used by supervisory agencies. Following the recommendations of the Basel Committee of Banking Supervision (2004), this is specified through a capital adequacy ratio (CAR), a measure incorporated in regulatory frameworks to oversee bank activity and prevent potential insolvency risks. Also, on the background of the financial crisis, the CAR is increasingly important and has been used in recent parametric and non-parametric research (see, e.g., Banker et al. (2010)).

Finally, considering the endogenous nature of risk and the underlying monitoring costs these may create, the impact of management practices on future performance and the quality of loan portfolios should be scrutinised. Thus, a third contribution is to assess the effect of executive turnover on the three defined measures. Corporate governance literature provides some insights on the benefits derived from monitoring. That is, accurate monitoring ex ante signals managers' performance, while ex post monitoring is used to reveal potential gains from executive turnovers (Hermalin and Weisbach 2003). Additionally, the analysis distinguishes between internally promoted CEOs and those contracted from the market of managers. We conjecture that an outsider CEO is more likely to improve performance by introducing new organisational practices, which is not expected in case of internally promoted CEOs who may maintain existing routines (Huson et al. 2004).

The empirical application considers and unique dataset of Costa Rican banks between 1998 and 2007. This setting is attractive since it previously underwent important changes in the regulatory 
framework jointly with enhancements in monitoring practices. By 1997 bank activity was deregulated among the different players and the supervisory institution had all its monitoring functions in place. Thus, apart from the generally available accounting variables, the dataset presents well-structured information on NPL and organisational architecture. Moreover, during the analysed time span the CAMELS rating system was introduced to evaluate the health of financial institutions (IMF 2003). ${ }^{1}$ Consequently, results also show bank performance surrounding this regulatory change.

The remainder of this paper is structured as follows. Section 2 provides a brief overview of the existing literature on bank performance and risk, and the consequences of executive turnover on performance. Section 3 develops the multidimensional efficiency measure. The Costa Rican banking industry is described in Section 4. In Section 5 the sample, variables and analysis stages are presented. Empirical results are found in Section 6, while the final section includes some concluding remarks.

\section{Theoretical underpinnings}

Technology advances and different episodes of financial fluctuations that have occurred over the past decades led many administrations from developing and developed economies to restructure financial sectors. These legal reforms were introduced to strengthen and stabilise the now deregulated financial systems, and focused on the structure of banking industries and the accurate functioning of supervisory institutions (Yildirim and Philippatos 2007; Banker et al. 2010).

Following these profound reforms banks were expected to consolidate and improve their performance as legal changes aimed at enhancing, among others, risk management practices. Banks thus exert a more diligent oversight of their operations in order to signal their safety to the market and defend their record to supervisory agencies. The quality of risk management activities in banks is usually linked to credit risk and the levels of capital available to absorb potential financial losses. In this sense, monitoring costs are especially relevant when they are related to NPL's management. In consonance with Berger and DeYoung (1997), Altunbas et al. (2000) and Van Hoose (2010), these variables are considered endogenous, and consequently they can be modelled as a function of management effort.

As a result, bank outcomes can be seen as an informative signal about the manager's unobserved ability. Using a principal-agent framework, Hermalin and Weisbach (1998) remark that performance offers information about the CEO's ability, and based on this observable measure the board evaluates the quality of the CEO. In addition, the board makes an estimate of the CEO's ability, which is proxied as the expected performance. Therefore, CEO turnover is a control mechanism linked to the monitoring task of the board (Laux 2010). In this context, efficient managers signal their superior skills by introducing policies that improve the monitoring over their portfolios, which

\footnotetext{
${ }^{1}$ Further details on the CAMELS methodology are presented in Section 4.
} 
decreases the probability of financial losses. To the contrary, poorly performing managers are more likely to incur higher losses due to ineffective loan portfolio monitoring.

The same reasoning holds for capital adequacy variables. Banks with low levels of capital adequacy are subject to higher scrutiny by regulators. Accordingly, under-capitalised banks will have a more reduced operational flexibility and a limited capacity to undertake strategic and financial actions, which could be detrimental to their performance (Hsiao et al. 2010). Efficient banks may have an orientation towards higher levels of capital adequacy. This is so not only to comply with the regulatory framework, but also to prevent insolvency risks associated with economic downturns. This way, highly capitalised banks are considered safe, disciplined and effective at containing risks, with potential positive effects on performance (Van Hoose 2010).

Banking literature on these issues is two folded. On the one hand, there are studies that link risk with performance. To name just a few, analyses exist for the US (Hughes and Mester 1998), Japan (Altunbas et al. 2000; Barros et al. 2012), South Korea (Park and Weber 2006; Banker et al. 2010), Taiwan (Hsiao et al. 2010), Brasil (Tabak et al. 2011), for various Latin American countries (Yildirim and Philippatos 2007) or for 87 countries around the world (Lozano-Vivas and Pasiouras 2010). Main findings indicate that the level of financial capital is positively related to efficiency and that using risk variables does not contribute to explaining scale inefficiencies (Hughes and Mester 1998; Altunbas et al. 2000). Evidence also suggests that NPL, as a measure of credit risk, negatively influence efficiency (Barros et al. 2012). Moreover, Yildirim and Philippatos (2007) and LozanoVivas and Pasiouras (2010) find that changes in regulatory frameworks jointly with introducing monitoring tools help improving efficiency levels, which emerge after a necessary adjustment period.

On the other hand, banks face problems derived from inefficient control and monitoring since conflicts of interests may frequently appear between principals, managers and depositors. Hence, research also scrutinises the relations between corporate governance mechanisms and performance. Nonetheless, similarly to the case of the link between risk and performance, few studies focus on the role of corporate governance on bank performance (Simpson and Gleason 1999; Macey and O'Hara 2003; Crespí et al. 2004; Laeven and Levine 2009).

To the best of our knowledge, these two research streams do not converge. In this paper we assess bank performance in the presence of risk, and introduce executive turnover to further isolate the effect that changes in management practices have on future performance. CEO replacements are crucial because they are often linked to the monitoring task of the board. There is a general consensus that the probability of CEO turnover is negatively related to performance (Huson et al. 2001; Hermalin and Weisbach 2003). In these cases, the board replaces a poor performing CEO to enhance firm performance. Existing findings suggest that improvements in shareholders' wealth and firm operations follow CEO turnover (Denis and Denis 1995; Huson et al. 2004).

At this point, it is important to notice that we focus on the origin of the successor rather than the type of departure. Even if distinguishing between voluntary and unexpected replacements is 
important, Hermalin and Weisbach (2003) and Huson et al. (2004) report that a voluntary CEO departure can be due to retirement or the acceptance of an external position. As a result, voluntary departures are not a signal of poor management or performance, and consequently, firms' future performance is expected to show smaller variations when compared with unexpected departures. In this way, not identifying the type of departure only adds noise to the proxy measure of executive turnover, which could lead to a downward biased estimate of performance changes.

Concerning the type of successor, banks can appoint an insider or outsider CEO. When banks decide to promote an internal candidate, no significant improvements in performance are expected, since the new CEO is more likely to continue with the traditional policies and routines of the bank. Alternatively, under the improved management hypothesis, a bank hires an outsider CEO to seek organisational change driven by this new agent who is not influenced by current mechanics. In this case, management quality is expected to enhance since outsiders usually introduce new practices that affect employees and improve performance. Accordingly, Borokhovich et al. (1996), Farrell and Whidbee (2003) or Huson et al. (2004) report significant positive changes in firm performance when CEO departures were followed by the appointment of a CEO from outside the firm.

Note that these agency theory arguments usually link active monitoring over managers to shareholder-oriented firms. Tirole (2001) shows that the major governance problem faced by firms with multiple stakeholders is to evaluate the quality of decision-making. Managers of stakeholderoriented firms cannot clearly know along which lines they will be evaluated. Thus, they can justify poor performance on the basis that other costly objectives more linked to the firm are better fulfilled. Similarly, firms with multiple stakeholders in the boardroom usually increase the cost of decisionmaking processes, which could lead to unfocussed goals and lower levels of decision quality (Tirole 2001). Due to these differences between shareholder- and stakeholder-oriented firms we conjecture that the sensibility of performance changes to CEO turnover may reveal the effectiveness of the governance system when performance is the dominant objective.

\section{Efficiency assessment in the presence of risk}

When dealing with multiple inputs yielding multiple outputs, efficiency literature usually employs DEA-based frontier methods grounded in economic production theory (see, e.g., Ray (2004) or Cooper et al. (2011)). DEA is a non-parametric technique that approximates the true but unknown technology, imposes no restrictions on the sample distribution, and does not require input or output prices. Efficient decision-making units shape the best practice frontier, while for the rest of units DEA computes an inefficiency score indicating their distance to the frontier. Thus, DEA is a complex benchmarking technique, where all analysed units are compared against each other. Note that the frontier is considered to be the best available technology (i.e. it is an approximation of the real 
technology), and therefore the model projects inefficient units on it without proposing to improve existing best practices.

Various DEA applications made way for developing diverse measures of inefficiency (see Ray (2004), Cooper et al. (2011) or the comprehensive review in Cook and Seiford (2009)). The growing awareness of the utility of DEA jointly with the need of well-defining inputs and outputs vectors led to new streams of research that not only account for inputs and desirable (good) outputs, but also accommodate undesirable (bad) outputs. The joint treatment of good and bad outputs is a current trend in the banking literature (Park and Weber 2006; Fukuyama and Weber 2010; Barros et al. 2012), and -to name just another research stream- has been widely employed for environmental studies (Färe et al. 2004; Kumar 2006; Sueyoshi and Goto 2011).

Let us first specify a general technology with good and bad outputs, which will subsequently be adapted to the particular case of the banking industry. As a baseline we define $\mathbf{x}=\left(x_{1}, \ldots, x_{N}\right) \in R_{+}^{N}, \mathbf{y}=\left(y_{1}, \ldots, y_{M}\right) \in R_{+}^{M}$ and $\mathbf{b}=\left(b_{1}, \ldots, b_{J}\right) \in R_{+}^{J}$ as the vectors of inputs, good outputs and bad outputs, respectively. These form the technology $T$, representing the set of all output vectors $(\mathbf{y}$ and $\mathbf{b})$ that can be produced using the input vector $(\mathbf{x}): T=\{(\mathbf{x}, \mathbf{y}, \mathbf{b}): \mathbf{x}$ can produce $(\mathbf{y}, \mathbf{b})\}$. Obviously, if one does not differentiate between good and bad outputs, then the input vector (x) would produce a total output vector given by the sum of vectors $\mathbf{y}$ and $\mathbf{b}$.

When modelling DEA with good and bad outputs, technology $(T)$ is usually defined assuming convexity, strong disposability of inputs and good outputs, and weak disposability of bad outputs. ${ }^{2}$ The strong disposability constraint imposes that a larger quantity of inputs can be used to produce the same quantity of outputs, or fewer good outputs and the same quantity of bad outputs can be produced from a certain level of inputs. The weak disposability constraint indicates that to reduce bad outputs (a costly process), a unit must produce less total outputs, given fixed input levels. Best practice frontiers are shaped for each year by $k=1, \ldots, K$ units in the corresponding period.

Yet another assumption, many times treated superficially, relates to the returns to scale. While assuming constant returns to scale has attractive properties, existing literature signalled that on most occasions the true technology experiences variable returns to scale (VRS). For instance, Chambers and Pope (1996) argued that restricting the returns to scale to constant should be avoided unless one analyses firms in long-run equilibrium. Moreover, assessments should report pure technical efficiency scores. This is because, contrary to technical efficiency under constant returns to scale, pure technical efficiency (VRS) only captures outcomes linked to managerial practices and reforming firm operations.

Defining a VRS technology that allows some outputs to be weakly disposable while other outputs are strongly disposable can be problematic due to computational issues. This technology was

\footnotetext{
${ }^{2}$ Strong disposability of inputs and good outputs implies that if $(x, y, b) \in T, 0 \leq y^{\prime} \leq y$ and $x^{\prime} \geq x$ (for each component) then $\left(x^{\prime}, y^{\prime}, b\right) \in T$. Weak disposability of bad outputs and good outputs implies that if $(x, y, b) \in T$ then $(x, \theta y, \theta b) \in T$ for $0 \leq \theta \leq 1$.
} 
accurately represented in Kuosmanen (2005). Furthermore, Kuosmanen's specification is the VRS technology that most closely incorporates all observed activities and satisfies strong disposability of inputs and good outputs, weak disposability of bad outputs, and convexity (Kuosmanen and Podinovski 2009; Podinovski and Kuosmanen 2011). It can be defined as follows:

$$
\begin{aligned}
T=\{(x, y, b): & \sum_{k=1}^{K} \theta^{k} \lambda^{k} y_{m}^{k} \geq y_{m}^{k^{\prime}} \geq 0, \quad m=1,2, \ldots, M \\
& \sum_{k=1}^{K} \theta^{k} \lambda^{k} b_{j}^{k}=b_{j}^{k^{\prime}}, \quad \mathrm{j}=1,2, \ldots, J \\
& \sum_{k=1}^{K} \lambda^{k} x_{n}^{k} \leq x_{n}^{k^{\prime}}, \quad \mathrm{n}=1,2, \ldots, N \\
& \sum_{k=1}^{K} \lambda^{k}=1 \\
& \lambda^{k} \geq 0, \quad k=1,2, \ldots, K \\
& \left.0 \leq \theta^{k} \leq 1, \quad k=1,2, \ldots, K\right\} .
\end{aligned}
$$

Note that (1) develops the traditionally employed technology that does not differentiate between good (y) and bad (b) outputs (i.e. a total output vector is produced using the input vector $\mathbf{x}$ ), and assumes convexity, VRS, and strong disposability of inputs and outputs. To reach this basic technology one just needs to completely remove both the bad outputs constraint and the abatement factor $(\theta)$ from expression (1). When modelling both good and bad outputs, this abatement factor enables the contraction of bad outputs only if accompanied by the contraction of good outputs.

However, depending on the analysed industry, bad outputs may not be linked to all good outputs. When dealing with environmental performance, as exemplified by Podinovski and Kuosmanen (2011), one can think that a good output such as steel is always linked to a bad output, such as harmful emissions. Nevertheless, in other sectors such as banking or service industries not all good outputs are related to the bad outputs. In our case, banks grant loans, which may prove to be good (performing) or bad (non-performing, i.e., NPL) depending on the intensity of monitoring and customers' behaviours. That is, the composition of the total loans portfolio is unaffected by other assets such as investment portfolios. To incorporate all these banking characteristics in efficiency analyses there is - to the best of our knowledge- no formalised modelling of NPL, as most existing studies assume the joint production of all bank outputs (see, e.g., Park and Weber (2006), Fukuyama and Weber (2010) or Barros et al. (2012)).

We thus propose to separate the vector of good outputs (y) into two vectors of good outputs linked to bad outputs $\left(\mathbf{u}=\left(u_{1}, \ldots, u_{I}\right) \in R_{+}^{I}\right)$ and good outputs not linked to bad outputs $\left(\mathbf{v}=\left(v_{1}, \ldots, v_{L}\right) \in R_{+}^{L}\right)$. That is, the production of the good output vector (u) implies that bad output (b) is also produced. Nonetheless, when producing the good output vector (v) there need not be any production of bad output (b). By using the abatement factor $(\theta)$ only for modelling the relation between bad outputs and their related good outputs, the technology is now: 


$$
\begin{aligned}
T=\{(x, u, v, b): & \sum_{k=1}^{K} \theta^{k} \lambda^{k} u_{i}^{k} \geq u_{i}^{k^{\prime}} \geq 0, \quad \mathrm{i}=1,2, \ldots, I \\
& \sum_{k=1}^{K} \theta^{k} \lambda^{k} b_{j}^{k}=b_{j}^{k^{\prime}}, \quad \mathrm{j}=1,2, \ldots, J \\
& \sum_{k=1}^{K} \lambda^{k} v_{l}^{k} \geq v_{l}^{k^{\prime}}, \quad 1=1,2, \ldots, L \\
& \sum_{k=1}^{K} \lambda^{k} x_{n}^{k} \leq x_{n}^{k^{\prime}}, \quad \mathrm{n}=1,2, \ldots, N \\
& \sum_{k=1}^{K} \lambda^{k}=1 \\
& \lambda^{k} \geq 0, k=1,2, \ldots, K \\
& \left.0 \leq \theta^{k} \leq 1, k=1,2, \ldots, K\right\} .
\end{aligned}
$$

Inefficiency is measured using the directional distance function proposed by Chambers et al. (1996). In its general form, the directional distance function seeks to simultaneously expand all types of good outputs, and contract bad outputs and inputs. Letting $\mathbf{g}=\left(g_{x}, g_{u}, g_{v}, g_{b}\right)$ be a directional vector, this function can be written as:

$$
\left.D\left(x^{k^{\prime}}, u^{k^{\prime}}, v^{k^{\prime}}, b^{k^{\prime}}\right)=\max \left\{\delta: x^{k^{\prime}}-\delta g_{x}, u^{k^{\prime}}+\delta g_{u}, v^{k^{\prime}}+\delta g_{v}, b^{k^{\prime}}-\delta g_{b}\right) \in T^{k}\right\} \text {. }
$$

However, the values of the directional vector $\mathbf{g}=\left(g_{x}, g_{u}, g_{v}, g_{b}\right)$ must be assigned. One could define $\mathbf{g}=$ $(1,1,1,1)$ to obtain the maximum unit expansion in all good outputs and simultaneous unit contraction in bad outputs and inputs. Another of the many possibilities may be a vector $\mathbf{g}=(x, 0,0,0)$ that would yield the percentage contraction in inputs, holding all outputs fixed. For this paper, the vector $\mathbf{g}=$ $(x, u, v, b)$ is used, similarly to the proportional distance function proposed by Briec (1997). Following equation (3), this specification estimates the simultaneous expansion in all good outputs, contraction in bad outputs and contraction in inputs. Since we assess bank performance from a managerial perspective, estimations are relevant at bank level. That is, the selected directional vector is in accordance with our objectives and framework as it allows taking into account bank specific characteristics.

This directional distance function can be computed as the solution to a linear programme. The non-linear technology in (2) can be linearised using the substitution from Kuosmanen (2005): $z^{k}=\theta^{k} \lambda^{k}$ and $\mu^{k}=\left(1-\theta^{k}\right) \lambda^{k}, \forall k$ so that $z^{k}+\mu^{k}=\lambda^{k}$. Next, to model the technology in (2) and compute expression (3) expanding all good outputs and contracting all bad outputs, one must solve:

$$
\begin{array}{ll}
D( & \left.x^{k^{\prime}}, u^{k^{\prime}}, v^{k^{\prime}}, b^{k^{\prime}}\right)=\max \delta \\
\text { s.t. } & \sum_{k=1}^{K} z^{k} u_{i}^{k} \geq u_{i}^{k^{\prime}}+\delta u_{i}^{k^{\prime}}, \quad \mathrm{i}=1,2, \ldots, I \\
& \sum_{k=1}^{K} z^{k} b_{j}^{k}=b_{j}^{k^{\prime}}-\delta b_{j}^{k^{\prime}}, \quad \mathrm{j}=1,2, \ldots, J \\
& \sum_{k=1}^{K}\left(z^{k}+\mu^{k}\right) v_{l}^{k} \geq v_{l}^{k^{\prime}}+\delta v_{l}^{k^{\prime}}, \quad 1=1,2, \ldots, L \\
& \sum_{k=1}^{K}\left(z^{k}+\mu^{k}\right) x_{n}^{k} \leq x_{n}^{k^{\prime}}-\delta x_{n}^{k^{\prime}}, \quad \mathrm{n}=1,2, \ldots, N \\
& \sum_{k=1}^{K}\left(z^{k}+\mu^{k}\right)=1 \\
& z^{k}, \mu^{k} \geq 0, k=1,2, \ldots, K .
\end{array}
$$


An efficient unit, situated on the best practice frontier, will have $D\left(x^{k^{\prime}}, u^{k^{\prime}}, v^{k^{\prime}}, b^{k^{\prime}}\right)=0$, whereas values of $D\left(x^{k^{\prime}}, u^{k^{\prime}}, v^{k^{\prime}}, b^{k^{\prime}}\right)>0$ show the degree of inefficiency of the analysed unit. Figure 1 presents a simplified representation of the directional distance function by illustrating the two-dimensional relation between the linked good and bad outputs. It also shows the difference between this function and the more traditional Shephard output distance function.

[Figure 1 about here]

On the one hand, the output distance function expands both linked good and bad outputs simultaneously, thus placing the output vector A on the boundary point $\mathrm{C}$. On the other hand, the directional distance function starts at point $\mathrm{A}$ and scales taking a direction for increasing good outputs and decreasing bad outputs to point B on the boundary. Therefore, $\delta u^{k}$ is added to the linked good output and $\delta b^{k^{\prime}}$ is subtracted from the bad output. Additionally, even if not observable in the figure, the good outputs not linked to the bads are expanded by $\delta v^{k^{\prime}}$, whereas inputs are contracted by $\delta x^{k^{\prime}}$.

\section{The Costa Rican banking industry: Deregulation processes and consolidation}

As in other developing economies, the deregulation of the Costa Rican banking sector aimed at improving monitoring activities as well as enhancing competitiveness among banks (Yildirim and Philippatos 2007). Before 1980, Costa Rican banks were tightly regulated in terms of interest rates and activities. In 1984, the Central Bank started to diminish its influence on interest rate pricing policies. Despite market constraints, the new participants in the banking system consolidated their positions. Another reform was launched in 1990, with important consequences for the financial system. First, the demand deposit monopoly was removed in 1992, and the private banks were allowed to capture resources from the population. Second, banks were allowed to grant loans and operate in foreign currency (US dollars).

In 1995 further reforms improved the supervision tasks and transparency of financial firms (IMF 2003). Due to the increase in the number of participants and the complexity of the banking system, the Central Bank created a supervisory agency, the Superintendent of Financial Entities (SUGEF). SUGEF monitors banks and operates as an independent organisation closely linked to the Central Bank. Similar policies were adopted in the securities and pension funds markets, where monitoring agencies were introduced. These latter reforms led to creating, in 1997, the National Council of Supervision of the Financial System. This is the main supervisory authority of the financial system, which monitors and coordinates the superintendents of the banking system, the stock market, and the pension fund operators (IMF 2003). Thus, full disclosure of bank activities started in 1997.

One last reform took place in 2001, when SUGEF introduced the CAMELS rating framework to enhance monitoring and evaluate in more detail the health of financial institutions (IMF 2003). This scheme facilitates monitoring over six major aspects of financial firms: capital adequacy, asset quality, management, earnings, liquidity, and sensitivity to market risk (SUGEF 2000). SUGEF uses 
the CAMELS framework as well as other tools to monitor all financial firms, including: state-owned commercial banks, private banks, mutual banks, cooperative banks, financial conglomerates, financial (non-banking) firms, credit unions and currency exchange offices. However, for the purposes of this paper, and given technology differences, we focus our analysis on those banks that operate under the same market conditions: the state-owned commercial banks, private banks, mutual banks and cooperative banks.

First, state-owned banks are fully controlled by the Costa Rican government. Jointly with the Central Bank, they are considered independent firms since politicians, in accordance with the financial law, do not influence their managerial decisions. This group controlled over $55 \%$ of the deposits and $46 \%$ of the total loans in 2007 . The second group includes private banks. In 2007, this group controlled $39 \%$ of the market loans and $26.5 \%$ of all deposits. The third group are the mutual banks, which in 2007 controlled $8.5 \%$ and $5 \%$ of the total deposits and loans, respectively. Their deposit portfolios are, similarly to the state-owned banks, entirely guaranteed by the government. The last group consists of cooperative banks. These firms are owned by cooperative members, however services are open to any type of customer. In 2007 these firms accounted for $8 \%$ and $10 \%$ of the deposits and loans markets, respectively.

It is worth noting that all Costa Rican banks operate under the same regulatory regime, and their capacity is unrestricted in terms of financial activities. At this point some considerations on the governance system are in order. First, banks differ widely in their organisational structure. On the one hand, private banks are shareholder-oriented firms with objectives that are more closely linked to profit maximisation. On the other hand, the rest of banks can be considered stakeholder-oriented firms. Apart from profit maximisation, their objectives also include facilitating the access to financial products and services, as well as other social purposes. Agency theory suggests that in the presence of multiple stakeholders firms exhibit lower monetary returns as compared to shareholder-oriented firms (Tirole 2001). In contrast, owners of shareholder-oriented firms have a common objective function and stronger incentives to exert a more active monitoring over managers (Shleifer and Vishny 1997; Macey and O'Hara 2003).

Second, and according to the financial law, banks' boards have to be fully composed of outside members. Consequently, the positions of Chairman and CEO cannot be vested in the same person. This is consistent with the concerns of several corporate governance activists about the importance of the firm's leadership structure. In this sense, Fama and Jensen (1983) and Jensen (1993) claim that concentration of decision and control rights in one individual reduces the board's effectiveness and leaves internal control mechanisms in a weaker position for disciplining poor managers. In conclusion, financial laws not only restrict the composition of the board of directors, but also introduce transparency mechanisms that facilitate the access to detailed information on financial operations and organisational architecture. 


\section{Sample, variables and analysis stages}

\subsection{Sample and Variables}

Data come from the Costa Rican Central Bank, are publicly available, and comprise information for all banks operating in the industry during 1998-2007. This period witnessed a limited numbers of entries and exits, and therefore we decided to use an unbalanced panel that encompasses all banks that participate in the market. The analysis consistently includes all three state-owned banks and the three mutual banks. The number of private banks decreased from 18 in 1998 to 11 in 2007. Finally, cooperative banks accounted for 25 between 1998 and 2003 and for 23 of the observations during 2004-2007. Thus, the total analysed sample comprises 454 firm-year observations. ${ }^{3}$

Banking efficiency literature identifies two main approaches for evaluating financial institutions (see the surveys of Berger and Humphrey (1997), Goddard et al. (2001) or Fethi and Pasiouras (2010)). These are the production and intermediation approaches. Under the production approach banks are viewed as producers of both deposits and loans. In this case inputs are labour and capital. The intermediation approach considers that banks attract deposits and purchased funds that are transformed into loans and financial investments. Hence, in this second definition, one should also introduce funds (i.e. the raw material to transform) as inputs.

This study utilises the intermediation approach, which is better suited to current banking activities (Berger and Humphrey 1997; Goddard et al. 2001). Apart from traditional balance sheet variables (e.g. deposits, assets, securities or loans), one should also account for other non-balance sheet dimensions. We partly capture these dimensions by adding gains from fee-based operations, which can be considered a non-traditional output (see, e.g., Illueca et al. (2009)). Moreover, due to the purpose of the study and the modelling of outputs, total loans are divided into performing (good) loan portfolio and non-performing (bad) loan portfolio. Table 1 presents the mean values of inputs and outputs for the analysed period. The selected inputs are: $\left(x_{1}\right)$ deposits, $\left(x_{2}\right)$ fixed assets, $\left(x_{3}\right)$ wages, and $\left(x_{4}\right)$ general administrative expenses. These thoroughly express funding, capital, labour and operating costs, respectively. Outputs are: $(u)$ performing loan portfolio, $(b)$ non-performing loan portfolio (NPL), $\left(v_{l}\right)$ securities (investment portfolio), and $\left(v_{2}\right)$ service fees (non-interest income).

\section{[Table 1 about here]}

Performing and non-performing loans are separated from the total loan portfolio using the rules set by the SUGEF. Specifically, NPL (be they mortgages, regular loans or corporate loans) are those past due for at least 90 days. These two output categories represent the linked good (u) and bad (b) outputs, as banks inevitably produce them simultaneously. In fact, NPL reflect credit risk and data show only positive values for both performing and non-performing loans. However, credit and the other considered outputs are mutually exclusive. Therefore, investment portfolio and service fees (v)

\footnotetext{
3 Section 4.3. further explains how data are used to construct the sequential best practice frontiers, the accounting measures and the subsequent second stage analyses.
} 
represent banking dimensions unrelated with the loan portfolio and are introduced as good outputs not linked to the undesirable output (NPL).

Efficiency scores derived from equation (4), jointly with accounting ratios, are employed as dependent variables in a second stage analysis. Descriptive statistics for the variables used in the second stage (accounting ratios and risk variables) are presented in Table 2. Accounting measures are constructed to evaluate economic performance, and are specified through return on assets computed as the ratio of profit to total assets (ROA), and the net interest margin (NIM), which is the difference between interest income and interest expense relative to total assets. It is important to remark that market-based measures cannot be used, as only three private banks were listed in 2007. Risk is measured via two measures commonly used in previous studies (Altunbas et al. 2000; Park and Weber 2006; Banker et al. 2010; Barros et al. 2012). First, the NPL ratio is given by non-performing loans relative to total loans. Second, a proxy variable for the capital adequacy ratio (CAR) is calculated as equity plus risk-weighted reserves divided by total assets.

[Tables 2 and 3 about here]

For the independent variables related to executive replacements, data in Table 3 presents the frequency of CEO turnover during 2000-2005 and the type of the incoming manager. We consider that a CEO turnover corresponds to a specific period only if the name of the top manager changes in two consecutive years. Thus, CEO turnover is captured by a dummy variable that takes the value of one if the top executive manager was replaced, and zero otherwise. In addition, two dummy variables take the value of one if the successor is from inside or outside the bank, and zero otherwise. An internal promotion is identified if the new CEO was either in the board or in the top management team in the year prior to her appointment. Finally, we introduce as control variables bank size, defined as the natural logarithm of total assets (lagged), interaction terms between size and ownership type, and time dummies to account for the influence of competition over time.

\subsection{Analysis stages}

The first analysis stage computes the efficiency scores following equation (4) and using the inputs and outputs specified in Section 5.1. There are, nonetheless, two more considerations necessary. On the one hand, literature expresses concerns linked to production possibilities. One example is found in Kumar and Rusell (2002), who point out that the true but unobservable frontier should include the knowledge accumulated from previous periods. On the other hand, pitfalls may appear in the presence of a reduced number of observations and a high number of input and output dimensions. Both concerns are addressed by using technology specifications including sequential reference sets (Tulkens and Vanden Eeckaut 1995). A sequential reference set implies that the current period technology depends not only on contemporary observations of inputs and outputs, but also on combinations from all previous periods. That is, the technology (i.e. the efficiency frontier) is 
constructed from all observed best practices of banks in the sample (for empirical applications see, e.g., Park and Weber (2006) or Banker et al. (2010)). However, when listing results, scores are reported for each bank only for the year under analysis. To enhance the accuracy and robustness of DEA estimations, we use data from years 1996 and 1997 to construct the technology of the banking industry. Subsequently, efficiency scores are reported yearly for the period 1998-2007.

A second stage analysis examines the effect of risk on bank performance (equation (5)). This effect on efficiency and accounting ratios is obtained by estimating the following regression for the full period:

$$
\begin{aligned}
\text { Performance }_{t}^{k} & =\alpha_{0}+\alpha_{1} \text { Performance }_{t-1}^{k}+\beta_{1} \text { Size }_{t-1}^{k}+\beta_{2} \text { Size }_{t-1}^{k} \times \text { Bank Type }_{t}^{k} \\
& +\beta_{3} \mathrm{CAR}_{t-1}^{k}+\beta_{4} \mathrm{NPL}_{t-1}^{k}+\psi_{t}+v_{t}^{k}
\end{aligned},
$$

where: $k=1, \ldots, K$ and $t=1, \ldots, T$ represent the cross-sectional units and the time periods, respectively; $\psi_{t}$ is the time-specific effect and $v_{t}^{k}$ is the error term. The disturbance takes the form $v_{t}^{k} \sim N\left[0, \sigma_{v}^{k}\right]$ when the dependent variable is the efficiency score. When ROA and NIM are the dependent variables, the error term takes the form $v_{t}^{k}=\varepsilon^{k}+\eta_{t}^{k}$, where $\varepsilon^{k}$ is the unobserved timeinvariant firm-specific effect that controls for unobservable heterogeneity, and $\eta_{t}^{k}$ is a stochastic error term that varies cross-time and cross-units. Note that all independent variables are introduced as lagged terms to control for potential endogeneity problems.

Our performance assessments imply using three different dependent variables: efficiency, ROA, and NIM. We are aware that the construction and the statistical properties of these variables differ widely, and therefore we are forced to use different techniques to assess the desired effects. Specifically, one difference appears when the absolute value of the efficiency score is the dependent variable (equation (5)). Given that the efficiency score is by definition $\delta^{k} \in[0,+\infty)$, we use a truncated regression since standard linear techniques are conceptually wrong and parameter estimates are inconsistent (Greene 2003). Thus, the model takes the form $\delta^{k} \approx \alpha+\beta X^{\prime k}+v^{k}$. Parameter estimates are obtained by the maximum likelihood method, and disturbances are constructed through parametric bootstrapping (2,000 replications) to derive more accurate error terms.

Accounting ratios (i.e. ROA and NIM) are unbounded by definition, so we can employ an econometric tool that allows taking into consideration the unobserved and constant heterogeneity among the analysed banks. Also, the presence of firm specific unobservable fixed effects that can be correlated with some explanatory variables should be accounted for. Consequently, the system generalised method of moments (GMM) estimator developed by Arellano and Bover (1995) is used. Note that the GMM procedure introduces the lagged dependent variable to control for serial dependence in this variable. Under this technique, the model is estimated in both levels and first differences, as level equations are simultaneously computed using differenced lagged regressors as instruments. Therefore, apart from controlling for individual heterogeneity, variations between firms 
can be retained (Blundell and Bond 1998). This is a key point, since the dynamic dimension of panel data permits to check response processes across time and to identify how banks' characteristics affect performance. Also, the system GMM estimators with adjusted standard errors are more efficient than the one-step estimator if the residuals are heteroskedastic.

As a measure of goodness of fit, model specification validity is confirmed through the Sargan test of overidentification. This procedure, proposed by Arellano and Bond (1991), tests whether the instrumental variables are uncorrelated to the residuals. Failure to reject the null hypothesis provides evidence that the instruments are valid. Additionally, we test for the presence of first and second degree serial correlation among disturbances. The presence of first degree serial correlation does not invalidate results as the first difference transformation is used. Failure to reject the null hypothesis of no second-order serial correlation indicates that orthogonality conditions and the instruments are valid.

Finally, we examine the effect that CEO turnover has on future performance changes over a five years time span centred on the replacement year. In doing so, all performance variables are utilised. Moreover, following Huson et al. (2004), we control for potential problems related to mean reversion of performance time-series. Details on this analysis and its results are presented in Section 6.3 .

\section{Empirical findings}

\subsection{Efficiency and accounting performance assessments}

This section first reports the efficiency assessment of the sector, modelled following equation (4). Note that, to illustrate the influence of NPL, we have also computed efficiency scores following a traditional definition of the technology that introduces the entire loan portfolio as a desirable output, and therefore does not account for credit risk. Figure 2 displays a $\mathrm{Li}$ test that compares the distributions of the two sets of results from this traditional definition and the specification that integrates NPL (i.e. equation (4)). Outcomes demonstrate that including credit risk has a clear effect, since the test confirms that the two distributions are significantly different at the $1 \%$ level. This corroborates that our specification is not only closer to the real banking technology in theoretical terms, but also makes a difference for the interpretation of the results. Thus, in what follows the scores that incorporate NPL are analysed.

[Figure 2 about here]

Keep in mind that scores of zero indicate efficient banks, whereas higher values point to the degree of inefficiency. For illustrative purposes, suppose that a fictitious bank has the following input and output vectors: $\left(x_{1}, x_{2}, x_{3}, x_{4}, u, v_{1}, v_{2}, b\right)=(600,310,200,150,400,320,70,100)$, and a corresponding efficiency coefficient $\delta=0.03$. To operate efficiently, this bank should expand performing loans $(u)$ by $400 \times 0.03=12$, investment portfolio $\left(v_{l}\right)$ by $320 \times 0.03=9.6$, and service 
fees $\left(v_{2}\right)$ by $70 \times 0.03=2.1$. It should also simultaneously contract NPL $(b)$ by $100 \times 0.03=3$, while reducing deposits $\left(x_{1}\right)$ by $600 \times 0.03=18$, fixed assets $\left(x_{2}\right)$ by $310 \times 0.03=9.3$, wages $\left(x_{3}\right)$ by $200 \times$ $0.03=6$, and administrative expenses $\left(x_{4}\right)$ by $150 \times 0.03=4.5$.

[Figure 3 and Table 4 about here]

In Figure 3 and Panel A of Table 4 one can notice that, after peaking in 1999, inefficiency shows a clear downward trend between 1999 and 2007. The overall mean inefficiency for the analysed period is 0.11 , with the highest value of 0.14 in 1999 and the lowest level of 0.07 in 2006 . This rather constant improvement is interrupted in 2002, when mean inefficiency rises from 0.11 in 2001 to 0.13 . A possible cause of this event may have been the impact of introducing the CAMELS rating system in 2001. Changes in regulatory frameworks aim at enhancing banks' competitiveness and arguably banks need a period to adapt to the new market conditions (Park and Weber 2006; Lozano-Vivas and Pasiouras 2010). Yet, it is worth noting that in our case reforms were not that drastic as compared to other Latin American countries because market conditions were relatively stable (Yildirim and Philippatos 2007).

As a result it is not surprising that the observed adjustment period is rather short and efficiency improvements are more accentuated after 2002. Mean inefficiency first drops to 0.12 in 2003 and subsequently to 0.09 in 2007. Evolutions of poor performers (see Q3) are similar and even more visible as inefficiency falls from 0.24 in 2004 to 0.12 in 2006. However, in 2007 inefficiency at Q3 rises to 0.19 , which could explain the increase in mean inefficiency. Therefore, results for the median seem more useful as they reflect a more reliable image of the distribution of inefficiency scores. Here, efficiency improvements are clearer as after inefficiency peaked in 2003 (0.09), it continuously decreased to 0.01 in 2007.

[Figure 4 about here]

Next, results for ROA and NIM are shown in Figure 4 and Panels B and C of Table 4. The aforementioned trends in efficiency are somewhat more difficult to observe in these accounting ratios, as variations are occasionally different. Dissimilarities appear since these one-dimensional variables do not capture the different types of banking activities.

Nevertheless, ROA confirms to a great extent the results obtained from the efficiency assessment. The three high variation periods in efficiency (1998-1999, 1999-2000 and 2004-2005) are also visible for ROA. However, whereas efficiency continued to improve after 2005, mean ROA does not illustrate this favourable trend (Figure 4). The lack of consistency between efficiency scores and ROA may be because ROA includes extraordinary results not related to the banks' core activity.

The NIM (see dashed line in Figure 4 and Panel C Table 4) is slightly but persistently decreasing after 2002. Note that the NIM could be considered a more useful profitability measure of current and future bank performance as its components (interest income and expenses) represent a large proportion of total bank revenues and costs (Van Hoose 2010). In our case, NIM decreases could signal enhanced market competition, which enforces performance and consequently narrows 
margin spreads (Bikker and Bos 2008). In addition, this is consistent with the consolidation and growth of the industry during the analysed period (Yildirim and Philippatos 2007).

\subsection{The effect of risk on performance}

The second stage analysis considers the above efficiency and accounting measures as dependent variables for the regressions defined in equation (5). The two risk ratios are introduced simultaneously in the regression as explanatory variables. ${ }^{4}$ Also, we examined the individual effect that risk exerts over performance. Results do not vary significantly relative to those presented in Table 5 for the full model. ${ }^{5}$ Observe that the Wald test of joint significance confirms that our model specifications are appropriate. Also, the Sargan test of overidentification indicates that instruments are valid, and autocorrelation tests corroborate that errors are not serially correlated.

[Table 5 about here]

Note that for the efficiency measure (see first column of Table 5), size is not significant. This confirms the robustness of the efficiency scores (equation (4)), as bank size is not an influential factor for shaping the estimated frontier. However, the size $\times$ private banks interaction term is negative and significant. This indicates that large shareholder-oriented banks tend to be more efficient as compared to the rest of banks.

Concerning the risk measures, only the NPL ratio has a significant impact over efficiency. That is, banks with higher proportion of NPL exhibit higher inefficiency levels. ${ }^{6}$ This ratio is useful for internal monitoring, and results are in line with the usual intuition that higher levels of NPL are costly for bank operations. This holds on most occasions for short-run analyses. Remark that the construction of equation (5) introduces the lagged term of the NPL ratio so its impact on efficiency represents a short-term effect. Thus, enhancing monitoring levels over the loan portfolio may be beneficial for bank efficiency. Alternatively, in the long-run high proportions of NPL could sometimes indicate higher risk taking. Incentives for risk taking may exist because equity owners could gain more if the bank experiences gains from risk taking (Van Hoose 2010).

As in the case of descriptive statistics, ROA regression results are rather consistent with the efficiency interpretations (see second column of Table 5). Size is negatively correlated to ROA, however the sign of the parameter estimate for the interaction term indicates that for private banks size matters for attaining superior ROA. Again, same as for the efficiency variable, findings for ROA confirm that higher NPL levels are negatively related to short-run performance. Moreover, this is in line with previous studies that employed similar variables (Banker et al. 2010; Hsiao et al. 2010).

\footnotetext{
${ }^{4}$ The correlation between these two variables is 0.056 , and is not statistically significant.

${ }^{5}$ Results of the individual regressions are available on request.

${ }^{6}$ Keep in mind that the NPL ratio is computed as NPL over total loans. In the efficiency model only NPL appear, and do so as an output. Furthermore, in DEA models, more or less of one output or input does not imply higher or lower inefficiency.
} 
Results for NIM corroborate the effect of size over accounting measures, and that private banks consistently have higher performance, regardless of the utilised dependent variable (see Table 5). For this accounting ratio, the CAR is the only significant risk variable. On the one hand, and more generally, significant CAR results signal that external monitoring helps banks obtain better accounting profitability results. The financial soundness of this variable reduces uncertainty and allows banks to have better market positions (Das and Ghosh 2006; Banker et al. 2010). In this way, banks could reduce fund rising costs and consequently increase their margin spreads. On the other hand, NPL are not significant for NIM probably because the costs of having NPL are not captured by this accounting ratio. To the contrary ROA comprises extraordinary results, including those related to the NPL portfolio.

\subsection{Performance changes following executive turnover}

This section complements the analysis by identifying executive turnovers and examining the effect that incoming managers have on future performance. We scrutinise the performance changes shown by banks during a five years period centred on the CEO turnover year. For analytical purposes, we follow the procedure used by Denis and Denis (1995) and Huson et al. (2004) to correct for potential problems linked to mean reversion of performance time-series. Thus, annual performance values are calculated for two sub-periods around CEO turnover: from year -2 to year -1 (ex ante), and from year -1 to year +2 ex post executive replacement (see Table 6 ). In order to correctly examine the performance path followed by banks before and after CEO turnover, we dropped from the sample three CEO replacements that took place between 2000 and 2005 because the tenure of the incoming CEO ended before year +2 .

To further corroborate the robustness of our results for the accounting ratios, we also estimated two alternative variables that account for market trends. These are median-adjusted ROA and NIM, which are obtained by subtracting, for each year, the median value of the corresponding measure for all firms in our sample. Note that DEA scores represent an efficiency assessment based on the technology of the sector (i.e. a benchmarking technique), and therefore adjusting to industrymedian values is not necessary. In this way, unadjusted and industry-adjusted performance changes following CEO turnover can isolate the effect of CEO turnover on performance changes from variations attributable to mean reversion of industry and firm specific components. Nevertheless, it is important to highlight that results considering changes in the median-adjusted ROA and NIM do not differ significantly from those obtained when performance is expressed as changes in unadjusted accounting variables.

[Figures 5 and 6 , and Table 6 about here]

Findings suggest that CEO turnover follows a period of deteriorating efficiency and that subsequent to replacements efficiency tends to improve relative to those banks that did not replace the 
CEO (Figure 5). Figure 6 plots, for the five years period centred on the turnover year, the mean values for the efficiency assessment. Furthermore, it differentiates CEO turnover followed by appointing an insider (dotted line) or an outsider (dashed line) from the solid line that includes all CEO replacements. One can notice that the positive effect of CEO turnover on future performance is most visible for those replacements followed by the appointment of a CEO from outside the bank. More specifically, results in Panel A of Table 6 show that mean inefficiency changed from 0.11 ( -2 to -1$)$ to $0.08(-1$ to +2$)$. Even if these inefficiency differences are not significantly different from zero, we observe that for CEO replacements followed by the appointment of an outsider, inefficiency significantly dropped from 0.12 ( -2 to -1$)$ to $0.07(-1$ to +2$)$ and that $56 \%$ of banks improved their efficiency level. To further explore this result we tested whether efficiency differences in those CEO replacements followed by the appointment of an outsider are statistically significant between shareholder- and stakeholder-oriented banks. We find that the positive effect that the appointment of an outsider has over future efficiency is more prevalent among shareholder-oriented banks. ${ }^{7}$

Similar findings are obtained for the accounting ratios (Panels B to E in Table 6). In the case of the unadjusted ROA and NIM (Panels B and D, respectively), performance significantly improved from 0.021 and 0.072 , respectively $(-2$ to -1$)$ to 0.027 and 0.081 , respectively ( -1 to +2$)$. Yet, performance improvements are statistically significant only for those CEO turnovers followed by the appointment of outsiders. Results are consistent for the median-adjusted performance variables. Once more, a more in-depth analysis reveals that shareholder-oriented banks benefit more from this disciplinary mechanism. ${ }^{8}$

These results corroborate that CEO turnover is an important control mechanism, and that its effectiveness becomes especially relevant when the incoming manager is an outsider. This could signal not only that managers from outside are not influenced by banks' internal routines, but also that outsiders are more likely to introduce new practices and seek organisational changes, which are expected to improve operating performance (Farrell and Whidbee 2003; Huson et al. 2004). Moreover, consistent with Tirole (2001), the cost of decision-making processes -in our case CEO turnover- may decrease in organisations where the board is more aligned towards a common objective.

\section{Concluding remarks}

This paper develops comprehensive monitoring tools for assessing bank performance. In doing so it first proposes a multidimensional efficiency measure that accounts for the joint production of desirable outputs (performing loans, securities and service fees) and an undesirable output that

\footnotetext{
${ }^{7}$ Wilcoxon signed-rank test: Z-value 1.682 and significant at the $10 \%$ level.

${ }^{8}$ In the case of ROA, the Wilcoxon signed-rank test shows a Z-value of -2.395 , significant at the $5 \%$ level. For NIM the Z-value is -2.497 , significant at the $5 \%$ level.
} 
represents credit risk (non-performing loans (NPL)). While some previous efforts to introduce risk in efficiency assessments exist, these have been scarce (see, e.g., the cost function approach of Hughes and Mester (1998) or Altunbas et al. (2000), or the use of NPL in Park and Weber (2006) and Barros et al. (2012)). In addition, incorporating risk in efficiency scores is increasingly important on the background of the financial crisis.

Our proposal adapts existing DEA specifications to the real banking technology that exhibits VRS and in which not all desirable outputs are linked to undesirable outputs. Specifically, NPL are strictly linked only to that output category that affects their levels (loans), while the rest of outputs are not related to NPL. When modelling the technology, NPL are introduced as an endogenous risk measure that proxies the quality of monitoring over loan portfolios.

Second, jointly with this multidimensional efficiency measure we employ traditional onedimensional accounting ratios to further examine bank performance. Note that it is useful to assess performance through various measures as their characteristics differ and they complement themselves towards reaching more in-depth interpretations. Results show general efficiency improvements over the analysed period. This positive evolution in terms of efficiency is mostly corroborated by the ROA results. The NIM slightly decreases, however its persistent downward trend could signal enhanced market competition and consolidation of banks (Bikker and Bos 2008). Another relevant finding indicates that changes in the regulatory framework, in our case the introduction of the CAMELS rating scheme, are initially followed by inefficiency increases. Efficiency subsequently improves after what is known as an adjustment period used by banks to adapt to the new regulations and market conditions (Grifell-Tatjé and Lovell 1999; Park and Weber 2006; Lozano-Vivas and Pasiouras 2010).

Further insights are provided by second stage regression analyses. These model bank performance as a function of their riskiness (i.e. NPL ratio and CAR). Risk ratios explain performance in various ways. On the one hand, variables capturing endogenous risk (NPL) exert a negative influence over efficiency and ROA. This could signal that poor monitoring over loan portfolios is costly for banks. On the other hand, the CAR has a positive impact on banks' NIM, showing that external monitoring may help banks to obtain better accounting profitability results.

If internal and external control mechanisms work properly, decisions related to appointing CEOs are more likely to improve future performance. We find that changes in top executives lead to greater efficiency and accounting performance. This mainly holds when the incoming CEO is hired from outside the bank. According to the improved management hypothesis, this could indicate that outsiders have a clearer influence on firm performance since they introduce new organisational practices (Huson et al. 2004). In addition, managers appointed from outside have stronger incentives to prove their potential quality to the board by showing their management skills. This is especially prevalent for shareholder-oriented banks. 


\section{References}

Altunbas, Y., Liu, M.H., Molyneux, P., Seth, R., 2000. Efficiency and risk in Japanese banking. Journal of Banking and Finance 24(10), 1605-1628.

Arellano, M., Bond, S., 1991. Some tests of specification for panel data: Monte Carlo evidence and an application to employment equations. Review of Economic Studies 58(2), 277-297.

Arellano, M., Bover, O., 1995. Another look at the instrumental-variable estimation of errorcomponent models. Journal of Econometrics 68(1), 29-51.

Banker, R., Chang, H., Lee, S.Y., 2010. Differential impact of Korean banking system reforms on bank productivity. Journal of Banking and Finance 34(7), 1450-1460.

Banker, R., Chang, H., Natarajan, R., 2005. Productivity change, technical progress, and relative efficiency change in the public accounting industry. Management Science 51(2), 291-304.

Barros, C.P. Managi, S., Matousek, R., 2012. The technical efficiency of the Japanese banks: Nonradial directional performance measurement with undesirable output. Omega 40(1), 1-8.

Basel Committee on Banking Supervision, 2004. International convergence of capital measurement and capital standards: A revised framework. http://www.bis.org/publ/bcbs107.pdf, accessed 1 February 2012.

Basel Committee on Banking Supervision, 2011. Range of methodologies for risk and performance alignment of remuneration. http://www.bis.org/publ/bcbs194.pdf, accessed 1 February 2012.

Berger, A.N., DeYoung, R., 1997. Problem loans and cost efficiency in commercial banks. Journal of Banking and Finance 21(6), 849-70.

Berger, A.N., Humphrey, D.B., 1997. The efficiency of financial institutions: International survey and directions for future research. European Journal of Operational Research 98(2), 175-212.

Bikker, J.A., Bos, J.W.B., 2008. Bank Performance. Routledge, New York.

Blundell, R., Bond, S., 1998. Initial conditions and moment restrictions in dynamic panel data models. Journal of Econometrics 87(1), 115-143.

Borokhovich, K., Parrino, R., Trapani, T., 1996. Outside directors and CEO selection. Journal of Financial and Quantitative Analysis 31(3), 337-355.

Briec, W., 1997. A Graph Type Extension of Farrell Technical Efficiency Measure. Journal of Productivity Analysis 8(1), 95-110.

Chambers, R.G., Pope, R.D., 1996. Aggregate productivity measures. American Journal of Agricultural Economics 78(5), 1360-1365.

Cook, W.D, Seiford, L.M., 2009. Data envelopment analysis (DEA) - Thirty years on. European Journal of Operational Research 192(1), 1-17.

Cooper, W.W., Seiford, L.M., Zhu, J., 2011. Handbook on Data Envelopment Analysis. $2^{\text {nd }}$ ed. Springer, New York. 
Crespí, R., García-Cestona, M., Salas, V., 2004. Governance mechanisms in Spanish banks: Does ownership matter? Journal of Banking and Finance 28(10), 2311-2330.

Das, A., Ghosh, S., 2006. Financial deregulation and efficiency: An empirical analysis of Indian banks during the post reform period. Review of Financial Economics 15(3), 193-221.

Denis, D.J., Denis, D.K., 1995. Firm performance changes following top management dismissals. Journal of Finance 50(4), 1029-1057.

Fama, E., Jensen, M., 1983. Separation of ownership and control. Journal of Law and Economics 26(2), 301-325.

Färe, R., Grosskopf, S., Hernandez-Sancho, F., 2004. Environmental performance: an index number approach. Resource and Energy Economics 26(4), 343-352.

Farrell, K.A., Whidbee, D.A., 2003. Impact of firm performance expectations on CEO turnover and replacement decisions. Journal of Accounting and Economics 36(1-3), 165-196.

Fethi, M.D., Pasiouras F., 2010. Assessing bank efficiency and performance with operational research and artificial intelligence techniques: A survey. European Journal of Operational Research 204(2), 189-198.

Fukuyama, H., Weber, W.L., 2010. A slacks-based inefficiency measure for a two-stage system with bad outputs. Omega 38(5), 398-409.

Goddard, J.A., Molyneux, P., Wilson, J.O.S., 2001. European Banking: Efficiency, Technology and Growth. Wiley, New York.

Greene, W., 2003. Econometric Analysis. $5^{\text {th }}$ ed. Upper Saddler River, New Jersey.

Grifell-Tatjé, E., Lovell, C.A.K., 1999. Profits and productivity. Management Science 45(9), 11771193.

Hermalin, B., Weisbach, M., 1998. Endogenously chosen boards of directors and their monitoring of the CEO. American Economic Review 88(1), 96-118.

Hermalin, B., Weisbach, M., 2003. Board of directors as an endogenously determined institution: A survey of the economic literature. FRBNY Economic Policy Review 9(1), 7-26.

Hsiao, H.C., Chang, H., Cianci, A.M., Huang, L.H., 2010. First financial restructuring and operating efficiency: Evidence from Taiwanese commercial banks. Journal of Banking and Finance 34(7), 1461-1471.

Hughes, J.P., Mester, L.J., 1998. Bank capitalization and cost: Evidence of scale economies in risk management and signalling. Review of Economics and Statistics 80(2), 314-325.

Huson, M.R., Parrino, R., Starks, L.T., 2001. Internal monitoring mechanisms and CEO turnover: A long-term perspective. Journal of Finance 56(6), 2265-2297.

Huson, M.R., Malatesta, P., Parrino, R., 2004. Managerial succession and firm performance. Journal of Financial Economics 74(2), 237-275.

Illueca, M., Pastor, J.M., Tortosa-Ausina, E., 2009. The effects of geographic expansion on the productivity of Spanish savings banks. Journal of Productivity Analysis 32(2), 119-143. 
International Monetary Fund (IMF), 2003. Costa Rica: Financial system stability assessment. IMF Country Report No. 03/103.

Jensen, M., 1993. Presidential address: The modern industrial revolution, exit and the failure of internal control systems. Journal of Finance 48(3), 831-880.

Kumar, S., 2006. Environmentally sensitive productivity growth: A global analysis using MalmquistLuenberger index. Ecological Economics 56(2), 280-293.

Kumar, S., Russell, R., 2002. Technological change, technological catch-up and capital deepening: Relative contributions to growth and convergence. American Economic Review 92(3), 527-548.

Kuosmanen, T., 2005. Weak disposability in nonparametric productivity analysis with undesirable outputs. American Journal of Agricultural Economics 87(4), 1077-1082.

Kuosmanen, T., Podinovski, V.V., 2009. Weak disposability in nonparametric production analysis: Reply to Färe and Grosskopf. American Journal of Agricultural Economics 91(2), 539-545.

Laeven, L., Levine, R., 2009. Bank governance, regulation and risk taking. Journal of Financial Economics 93(2), 259-275.

Laux, V., 2010. Effects of litigation risk on board oversight and CEO incentive pay. Management Science 56(6), 938-948.

Lozano-Vivas, A., Pasiouras, F., 2010. The impact of non-traditional activities on the estimation of bank efficiency: International evidence. Journal of Banking and Finance 34(7), 1436-1449.

Macey, J., O'Hara, M., 2003. The corporate governance of banks. FRBNY Economic Policy Review 9(1), 91-107.

McAllister, P.H., McManus, D., 1993. Resolving the scale efficiency puzzle in banking. Journal of Banking and Finance 17(2-3), 389-405.

Park, K.H., Weber W.L., 2006. A note on efficiency and productivity growth in the Korean banking industry, 1992-2002. Journal of Banking and Finance 30(8), 2371-2386.

Podinovski, V.V., Kuosmanen, T., 2011. Modelling weak disposability in data envelopment analysis under relaxed convexity assumptions. European Journal of Operational Research 211(3), 577585.

Ray, S.C., 2004. Data Envelopment Analysis: Theory and Techniques for Economics and Operations Research. Cambridge University Press, New York.

Shleifer, A., Vishny, R., 1997. A survey of corporate governance. Journal of Finance 52(2), 737-783.

Simpson, G., Gleason, A., 1999. Board structure, ownership, and financial distress in banking firms. International Review of Economics and Finance 8(3), 281-292.

Sueyoshi, T., Goto, M., 2011. Methodological comparison between two unified (operational and environmental) efficiency measurements for environmental assessment. European Journal of Operational Research 210(3), 684-693.

Superintendent of Banks (SUGEF), 2000. Reglamento para juzgar la situación económica-financiera de las entidades fiscalizadas. Costa Rican Central Bank, Acuerdo SUGEF 24-00. 
Tabak, B.M., Fazio, D.M., Cajueiro, D.O., 2011. The effects of loan portfolio concentration on Brazilian banks' return and risk. Journal of Banking and Finance 35(11), 3065-3076.

Tirole, J., 2001. Corporate governance. Econometrica 69(1), 1-35.

Tulkens, H., Vanden Eeckaut, P., 1995. Non-parametric efficiency, progress and regress measures for panel data: Methodological aspects. European Journal of Operational Research 80(3), 474-499. Van Hoose, D., 2010. The Industrial Organization of Banking. Springer, Berlin.

Yildirim, H.S., Philippatos, G.C., 2007. Restructuring, consolidation and competition in Latin American banking markets. Journal of Banking and Finance 31(3), 629-639. 
Figure 1. The directional distance function with good and bad outputs

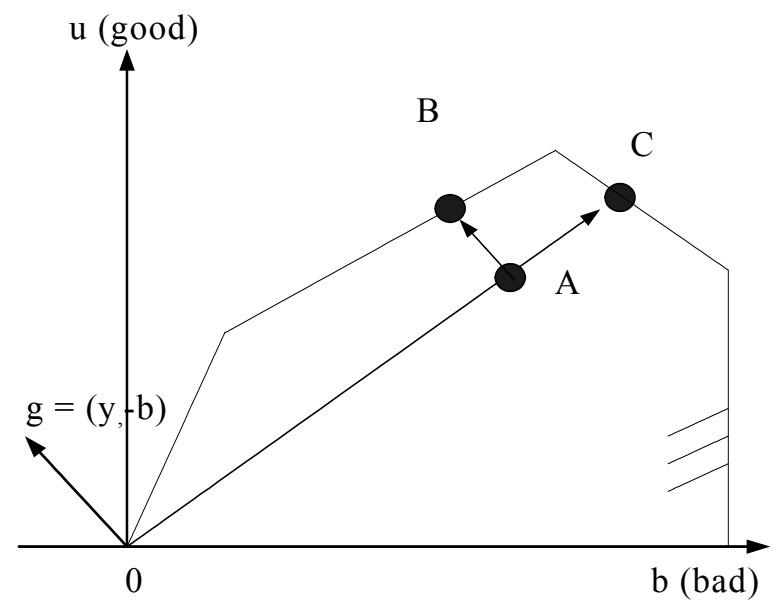

Figure 2. Li test: Traditional vs. Modelling non-performing loans (NPL)

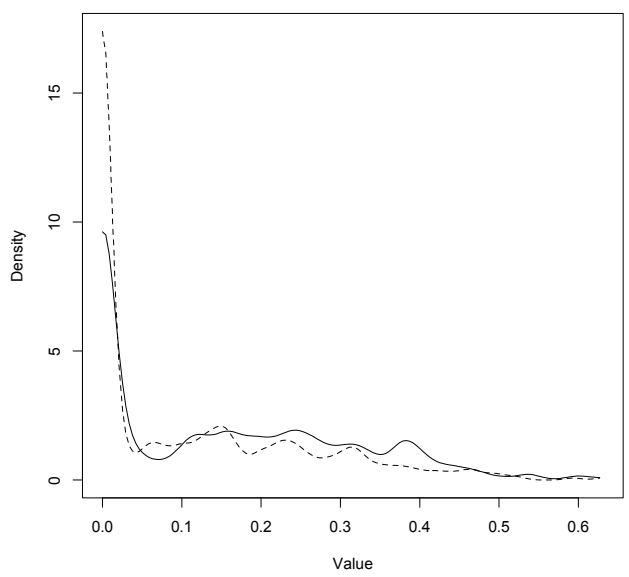

The solid line illustrates the distribution of the traditional model scores, whereas the dashed line stands for the NPL output model. Li test t-statistic: 8.9, significant at the 0.01 level.

Figure 3. Efficiency scores - Mean values

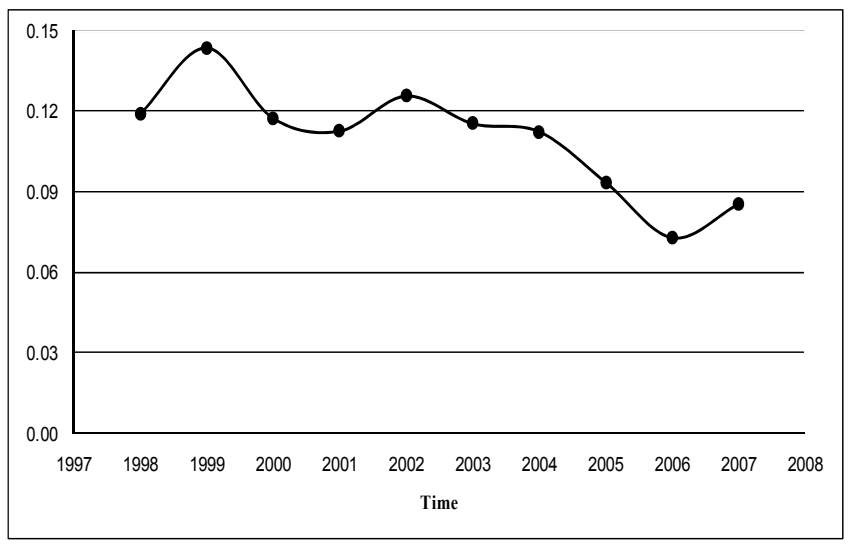


Figure 4. Accounting performance - Mean values

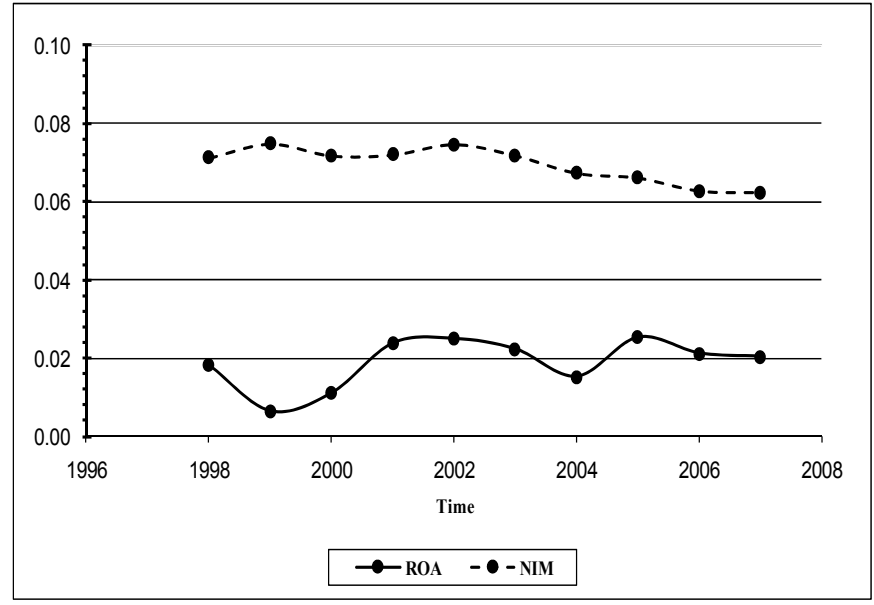

Figure 5. Efficiency changes around CEO turnover

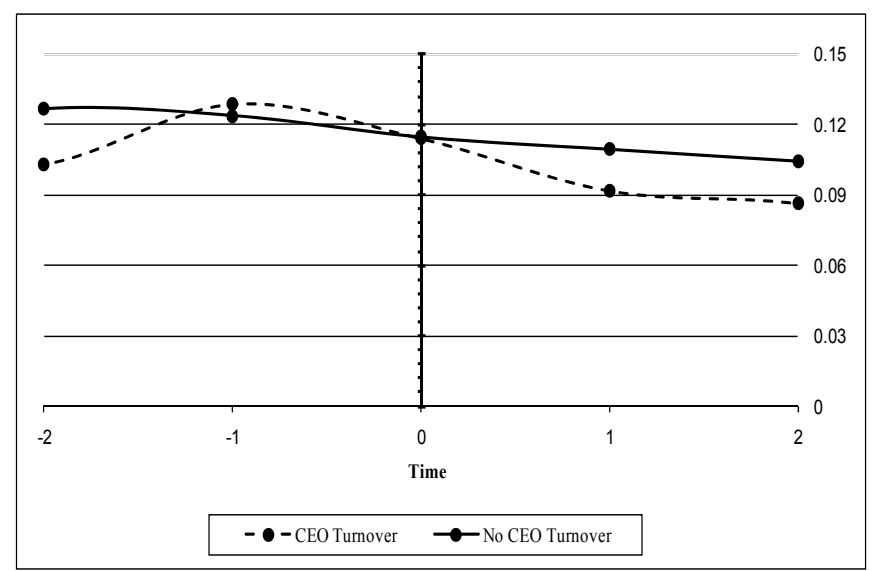

Figure 6. Efficiency changes around CEO turnover - Insiders vs. Outsiders

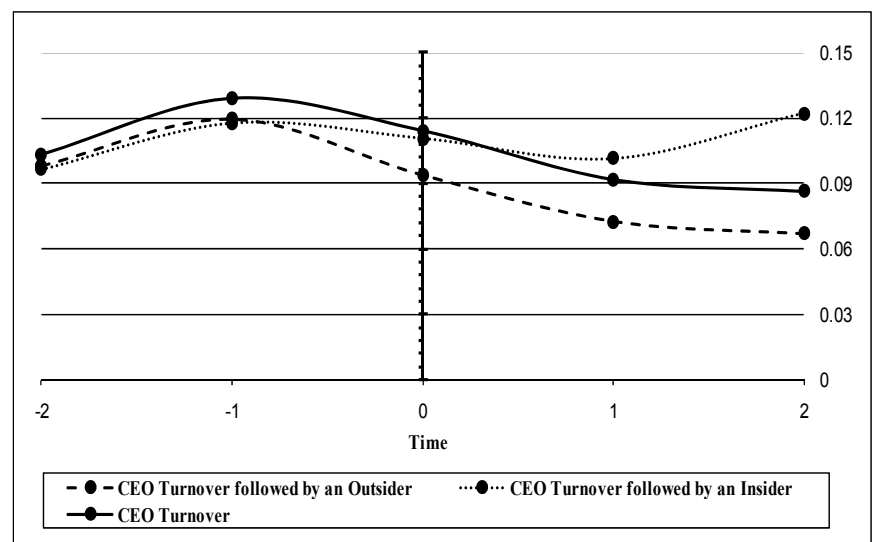


Table 1. Inputs and outputs - Mean values

\begin{tabular}{|cccccccccc|}
\hline Year & $\begin{array}{c}\text { Deposits } \\
\left(\boldsymbol{x}_{\boldsymbol{1}}\right)\end{array}$ & $\begin{array}{c}\text { Fixed } \\
\text { assets } \\
\left(\boldsymbol{x}_{\mathbf{2}}\right)\end{array}$ & $\begin{array}{c}\text { Wages } \\
\left(\boldsymbol{x}_{\boldsymbol{3}}\right)\end{array}$ & $\begin{array}{c}\text { Admin. } \\
\mathbf{e x p e n s e s} \\
\left(\boldsymbol{x}_{\mathbf{4}}\right)\end{array}$ & $\begin{array}{c}\text { Total } \\
\text { loans } \\
(\boldsymbol{u}+\boldsymbol{b})\end{array}$ & $\begin{array}{c}\text { Performing } \\
\text { loans } \\
(\boldsymbol{u})\end{array}$ & $\begin{array}{c}\text { NPL } \\
(\boldsymbol{b})\end{array}$ & $\begin{array}{c}\text { Securities } \\
\left(\boldsymbol{v}_{\boldsymbol{l}}\right)\end{array}$ & $\begin{array}{c}\text { Service } \\
\text { fees } \\
\left(\boldsymbol{v}_{\boldsymbol{2}}\right)\end{array}$ \\
\hline 1998 & 39,882 & 4,179 & 2,353 & 1,240 & 31,462 & 30,559 & 903 & 21,882 & 1,148 \\
1999 & 42,153 & 4,520 & 2,560 & 1,551 & 34,699 & 33,814 & 885 & 24,606 & 1,259 \\
2000 & 48,164 & 3,607 & 2,711 & 1,798 & 43,582 & 42,078 & 1,505 & 26,806 & 1,503 \\
2001 & 48,366 & 3,699 & 3,060 & 2,062 & 51,533 & 50,356 & 1,177 & 26,589 & 1,654 \\
2002 & 51,192 & 4,223 & 3,333 & 2,203 & 57,471 & 55,654 & 1,818 & 30,014 & 1,769 \\
2003 & 54,620 & 3,766 & 3,553 & 2,373 & 64,230 & 63,167 & 1,063 & 31,815 & 2,204 \\
2004 & 75,482 & 4,241 & 4,452 & 2,621 & 74,623 & 73,176 & 1,447 & 48,131 & 2,690 \\
2005 & 81,555 & 4,431 & 4,736 & 2,832 & 85,528 & 84,382 & 1,146 & 48,434 & 3,013 \\
2006 & 94,481 & 4,824 & 5,209 & 3,219 & 106,775 & 105,399 & 1,376 & 50,620 & 3,533 \\
2007 & 100,890 & 5,377 & 5,684 & 3,483 & 136,512 & 134,971 & 1,541 & 40,514 & 4,121 \\
Total & 61,608 & 4,255 & 3,654 & 2,271 & 65,667 & 64,392 & 1,275 & 33,966 & 2,196 \\
\hline
\end{tabular}

The sample includes information for the Costa Rican banking firms between 1998 and 2007. All monetary values are expressed in millions of 2007 Costa Rican colones, and are deflated with respect to inflation.

Table 2. Accounting performance and risk variables - Descriptive statistics

\begin{tabular}{|l|c|c|c|c|c|}
\cline { 2 - 6 } \multicolumn{1}{c|}{} & Mean & S.D. & Q1 & Median & Q3 \\
\hline Total assets & 124,359 & 325,158 & 3,249 & 23,547 & 75,240 \\
ROA & 0.0185 & 0.0511 & 0.0094 & 0.0159 & 0.0292 \\
NIM & 0.0699 & 0.0377 & 0.0432 & 0.0589 & 0.0877 \\
NPL ratio & 0.0249 & 0.0485 & 0.0076 & 0.0149 & 0.0263 \\
CAR & 0.2362 & 0.1715 & 0.1133 & 0.1661 & 0.3160 \\
\hline
\end{tabular}

The sample includes information for the Costa Rican banking firms between 1998 and 2007. Total assets are expressed in millions of 2007 Costa Rican colones. Return on assets (ROA) is defined as the ratio of net profit divided by total assets. The net interest margin (NIM) is the difference between interest income and interest expense relative to total assets. The capital adequacy ratio (CAR) divides equity and risk-weighted reserves by total assets. For the non-performing loans (NPL) ratio, NPL are divided by total loans. Number of observations: 454.

Table 3. Frequency table for CEO turnover during 2000-2005

\begin{tabular}{|l|cc|cc|cc|cc|cc|cc|cc|}
\cline { 2 - 14 } & \multicolumn{2}{|c|}{$\mathbf{2 0 0 0}$} & \multicolumn{2}{c|}{$\mathbf{2 0 0 1}$} & \multicolumn{2}{c|}{$\mathbf{2 0 0 2}$} & \multicolumn{2}{c|}{$\mathbf{2 0 0 3}$} & \multicolumn{2}{c|}{$\mathbf{2 0 0 4}$} & \multicolumn{2}{c|}{$\mathbf{2 0 0 5}$} & \multicolumn{2}{c|}{ Total } \\
& $\mathbf{N}$ & $\mathbf{\%}$ & $\mathbf{N}$ & $\mathbf{\%}$ & $\mathbf{N}$ & $\mathbf{\%}$ & $\mathbf{N}$ & $\mathbf{\%}$ & $\mathbf{N}$ & $\mathbf{\%}$ & $\mathbf{N}$ & $\%$ & $\mathbf{N}$ & $\%$ \\
\hline $\boldsymbol{\Delta C E O}$ & $\mathbf{5}$ & $\mathbf{1 . 0 0}$ & $\mathbf{4}$ & $\mathbf{1 . 0 0}$ & $\mathbf{3}$ & $\mathbf{1 . 0 0}$ & $\mathbf{8}$ & $\mathbf{1 . 0 0}$ & $\mathbf{3}$ & $\mathbf{1 . 0 0}$ & $\mathbf{6}$ & $\mathbf{1 . 0 0}$ & $\mathbf{2 9}$ & $\mathbf{1 . 0 0}$ \\
Insider & 2 & 0.40 & 0 & 0.00 & 0 & 0.00 & 5 & 0.63 & 0 & 0.00 & 1 & 0.17 & 8 & 0.38 \\
Outsider & 3 & 0.60 & 4 & 1.00 & 3 & 1.00 & 3 & 0.38 & 3 & 1.00 & 5 & 0.83 & 21 & 0.62 \\
\hline
\end{tabular}


Table 4. Performance measures - Descriptive statistics

\begin{tabular}{|crccccc|}
\hline \multicolumn{2}{|c}{ Panel A: Efficiency (DEA) } & & & & \\
Year & Obs.* & Mean & S.D. & Q1 & Median & Q3 \\
1998 & 51 & 0.1188 & 0.1565 & 0.0000 & 0.0346 & 0.1904 \\
1999 & 50 & 0.1436 & 0.1745 & 0.0000 & 0.0843 & 0.2454 \\
2000 & 50 & 0.1174 & 0.1559 & 0.0000 & 0.0000 & 0.2286 \\
2001 & 47 & 0.1126 & 0.1525 & 0.0000 & 0.0184 & 0.2086 \\
2002 & 47 & 0.1257 & 0.1455 & 0.0000 & 0.0685 & 0.2243 \\
2003 & 46 & 0.1154 & 0.1300 & 0.0000 & 0.0872 & 0.2172 \\
2004 & 42 & 0.1123 & 0.1259 & 0.0000 & 0.0495 & 0.2399 \\
2005 & 40 & 0.0934 & 0.1092 & 0.0000 & 0.0183 & 0.1757 \\
2006 & 40 & 0.0729 & 0.0958 & 0.0000 & 0.0143 & 0.1172 \\
2007 & 39 & 0.0856 & 0.1100 & 0.0000 & 0.0084 & 0.1917 \\
Total & 452 & 0.1113 & 0.1398 & 0.0000 & 0.0300 & 0.2028 \\
\hline Panel B: ROA & & & & & \\
Year & Obs. & Mean & S.D. & Q1 & Median & Q3 \\
1998 & 52 & 0.0181 & 0.0325 & 0.0065 & 0.0108 & 0.0296 \\
1999 & 51 & 0.0064 & 0.1083 & 0.0056 & 0.0115 & 0.0297 \\
2000 & 50 & 0.0110 & 0.0685 & 0.0049 & 0.0129 & 0.0255 \\
2001 & 47 & 0.0237 & 0.0237 & 0.0087 & 0.0159 & 0.0405 \\
2002 & 47 & 0.0249 & 0.0257 & 0.0092 & 0.0173 & 0.0390 \\
2003 & 46 & 0.0222 & 0.0209 & 0.0092 & 0.0161 & 0.0319 \\
2004 & 42 & 0.0153 & 0.0675 & 0.0126 & 0.0169 & 0.0296 \\
2005 & 40 & 0.0252 & 0.0181 & 0.0144 & 0.0196 & 0.0284 \\
2006 & 40 & 0.0212 & 0.0155 & 0.0125 & 0.0160 & 0.0233 \\
2007 & 39 & 0.0203 & 0.0175 & 0.0108 & 0.0162 & 0.0234 \\
Total & 454 & 0.0190 & 0.0468 & 0.0095 & 0.0159 & 0.0284 \\
\hline Panel C: NIM & & & & & \\
Year & Obs. & Mean & S.D. & $\mathbf{Q 1}$ & Median & $\mathbf{Q 3}$ \\
1998 & 52 & 0.0712 & 0.0457 & 0.0404 & 0.0576 & 0.0986 \\
1999 & 51 & 0.0748 & 0.0501 & 0.0398 & 0.0594 & 0.1179 \\
2000 & 50 & 0.0718 & 0.0443 & 0.0387 & 0.0589 & 0.0876 \\
2001 & 47 & 0.0720 & 0.0383 & 0.0411 & 0.0635 & 0.0912 \\
2002 & 47 & 0.0747 & 0.0364 & 0.0472 & 0.0641 & 0.0932 \\
2003 & 46 & 0.0718 & 0.0317 & 0.0465 & 0.0658 & 0.0933 \\
2004 & 42 & 0.0673 & 0.0296 & 0.0448 & 0.0564 & 0.0781 \\
2005 & 40 & 0.0661 & 0.0320 & 0.0438 & 0.0563 & 0.0829 \\
2006 & 40 & 0.0628 & 0.0271 & 0.0467 & 0.0502 & 0.0844 \\
Total & 454 & 0.0624 & 0.0273 & 0.0430 & 0.0542 & 0.0748 \\
2007 & 0.0689 & 0.0386 & 0.0421 & 0.0569 & 0.0862 \\
\hline
\end{tabular}

* Note that for the efficiency measure the number of observations stands for the number of reported scores, whereas the sequential technology also includes banks from all previous periods. 
Table 5. Regression results - Overall sector performance

\begin{tabular}{|l|c|c|c|}
\cline { 2 - 4 } \multicolumn{1}{c|}{} & $\begin{array}{c}\text { Efficiency } \\
\text { (DEA) }\end{array}$ & ROA & NIM \\
\hline Size $($ ln assets) $t-1$ & 0.0136 & $-0.0208 * *$ & $-0.0156 * * *$ \\
Size $t-1$ - private banks & $(0.0098)$ & $(0.0102)$ & $(0.0041)$ \\
& $-0.0084 * * *$ & $0.0278 * *$ & $0.0223 * * *$ \\
CAR $t-1$ & $(0.0022)$ & $(0.0128)$ & $(0.0065)$ \\
& -0.0640 & -0.0154 & $0.1156 * * *$ \\
NPL ratio $t-1$ & $(0.0736)$ & $(0.0649)$ & $(0.0163)$ \\
Time dummies & $1.6613 * *$ & $-0.6470 * * *$ & -0.0309 \\
Intercept & $(0.7579)$ & $(0.1146)$ & $(0.0422)$ \\
Pseudo R2 & Yes & Yes & Yes \\
Log likelihood & -0.1089 & $0.2168 *$ & $0.1702 * * *$ \\
Wald test (chi2) & $(0.1766)$ & $(0.1160)$ & $(0.0622)$ \\
Sargan test & 0.0433 & & \\
Test for AR1 & 205.9096 & & $629.65 * * *$ \\
Test for AR2 & $40.62 * * *$ & $135.52 * * *$ & 37.9597 \\
Observations & & 40.9292 & $-1.7433 *$ \\
& & -0.9740 & 0.4941 \\
& & 0.1012 & 433 \\
\hline
\end{tabular}

For the truncated regression using the efficiency score as dependent variable bootstrapped standard errors $(2,000$ iterations) are presented in brackets. For the GMM regressions (NIM and ROA) robust standard errors are presented in brackets. $*, * *, * * *$ indicate significance at the $0.10,0.05$, and 0.01 level, respectively.

Table 6. Performance changes around CEO turnover

\begin{tabular}{|c|c|c|c|c|}
\hline & \multicolumn{2}{|c|}{ Governance intervention } & \multicolumn{2}{|c|}{ Successor } \\
\hline & $\begin{array}{l}\text { No CEO } \\
\text { turnover }\end{array}$ & CEO turnover & Insider & Outsider \\
\hline $\begin{array}{l}\text { Panel A: Efficiency (DEA) } \\
-2 \text { to }-1 \\
-1 \text { to }+2 \\
\text { Z Wilcoxon signed rank test }\end{array}$ & $\begin{array}{c}0.1251(47: 53) \\
0.1126(60: 40) \\
2.086 * * \\
\end{array}$ & $\begin{array}{c}0.1133(52: 48) \\
0.0810(52: 48) \\
1.308 \\
\end{array}$ & $\begin{array}{c}0.1069(57: 43) \\
0.1130(40: 60) \\
-0.674 \\
\end{array}$ & $\begin{array}{c}0.1155(50: 50) \\
0.0721(56: 44) \\
1.938 * \\
\end{array}$ \\
\hline $\begin{array}{l}\text { Panel B: ROA } \\
-2 \text { to }-1 \\
-1 \text { to }+2 \\
Z \text { Wilcoxon signed rank test }\end{array}$ & $\begin{array}{c}0.0237(48: 52) \\
0.0235(47: 53) \\
-0.109 \\
\end{array}$ & $\begin{array}{l}0.0212(50: 50) \\
0.0266(52: 48) \\
-2.159 * *\end{array}$ & $\begin{array}{c}0.0179(29: 71) \\
0.0182(40: 60) \\
-0.405\end{array}$ & $\begin{array}{c}0.0224(57: 43) \\
0.0289(61: 39) \\
-2.286 * *\end{array}$ \\
\hline $\begin{array}{l}\text { Panel C: Median adjusted } \\
\text { ROA } \\
-2 \text { to }-1 \\
-1 \text { to }+2 \\
\text { Z Wilcoxon signed rank test }\end{array}$ & $\begin{array}{c}0.0092(43: 57) \\
0.0072(38: 62) \\
3.716 * * * \\
\end{array}$ & $\begin{array}{c}0.0057(43: 57) \\
0.0104(65: 35) \\
-1.217 \\
\end{array}$ & $\begin{array}{c}0.0023(57: 43) \\
0.0016(40: 60) \\
0.405\end{array}$ & $\begin{array}{c}0.0068(38: 62) \\
0.0128(67: 33) \\
-1.677^{*}\end{array}$ \\
\hline $\begin{array}{l}\text { Panel D: NIM } \\
-2 \text { to }-1 \\
-1 \text { to }+2 \\
Z \text { Wilcoxon signed rank test }\end{array}$ & $\begin{array}{c}0.0731(48: 52) \\
0.0697(39: 61) \\
3.883 * * * \\
\end{array}$ & $\begin{array}{c}0.0717(36: 64) \\
0.0805(61: 39) \\
-1.825 * \\
\end{array}$ & $\begin{array}{c}0.0652(14: 84) \\
0.0635(80: 20) \\
-0.405 \\
\end{array}$ & $\begin{array}{c}0.0738(43: 57) \\
0.0852(56: 44) \\
-1.720 * \\
\end{array}$ \\
\hline $\begin{array}{l}\text { Panel E: Median adjusted } \\
\text { NIM } \\
-2 \text { to }-1 \\
-1 \text { to }+2 \\
\text { Z Wilcoxon signed rank test }\end{array}$ & $\begin{array}{c}0.0118(47: 53) \\
0.0097(51: 49) \\
1.990 * * \\
\end{array}$ & $\begin{array}{c}0.0112(61: 39) \\
0.0246(52: 48) \\
-2.159 * *\end{array}$ & $\begin{array}{c}0.0024(57: 43) \\
0.0030(40: 60) \\
-0.994\end{array}$ & $\begin{array}{c}0.0142(62: 38) \\
0.0306(56: 44) \\
-1.982 * *\end{array}$ \\
\hline
\end{tabular}

Percentage of firms with positive and negative changes in performance are reported in brackets (i.e. figures should be read as "percentage of positive changes : percentage of negative changes"). *, **, *** indicate significance at the $0.10,0.05$, and 0.01 level, respectively. 